\title{
Coproscopy a Premordial Diagnostic Tool in Avian Parasitology
}

\author{
Berghiche Amine ${ }^{1 *}$, Boulebda Nadji ${ }^{1}$, Aouadi Aml², Ghemaidia Malek², Tarek Khenenou ${ }^{2}$ \\ ${ }^{1}$ Laboratory of Science and Technic of living Mohamed Cherrif Messaadia University, Souk Ahras, Algeria \\ ${ }^{2}$ Agro veterinary institute, Taoura, Mohamed Cherrif Messaadia University, Souk Ahras, Algeria
}

\begin{abstract}
Parasitic diseases are a problem that affects all poultry farms, whether large commercial or small backyard farms, where economic losses can be significant. In this study, a survey on intestinal parasites of chickens was carried out in the Souk Ahras region over a period of 6 months. The faeces of a total of 90 chickens collected from different farm types were examined by flotation to detect gastrointestinal parasites. The results obtained from these chickens showed that all the examined faeces were $100 \%$ infected. The qualitative analysis showed a flocculation of helminths and protozoa's oocytes across the taken chicken samples at different farms with different infection percentage. Broiler chicken reported infected with Ascaridia (50\%); Heterakis (35\%) and Eimeria (15\%). The laying hen infected with Ascaridia, Heterakis and coccidial oocysts which represented by $33.33 \%, 33.33 \%$ and $33.34 \%$, respectively. However, for the local chiken, Ascaridia: (40\%) Heterakis (35\%), Eimeria (15\%), Syngamus $(5 \%)$ and Capillaria $(5 \%)$ were recorded. The high infection rate recorded in the study area suggested that an intensive poultry management system and regular chicken control should be held.
\end{abstract}

Keywords: Qualitative analysis, parasitic diseases, Souk Ahras, Oocytes, Poultry farming.

\section{INTRODUCTION}

Chicken is generally considered one of the oldest domesticated birds (Oueslati et al., 2020). In Algeria the poultry sector occupies a special social and economic position, with $9.84 \%$ of animal production (Debbou-Iouknane et al., 2018). In addition, poultry farming produces on average 340,000 tons of white meat and more than 4.8 billion eggs annually (Allaoui and Bennon, 2013). However, the poultry sector is facing serious multifactorial problems (Berghiche et al., 2018a), both in intensive and traditional extensive systems, among these constraints and, in the first place, parasitic diseases of the digestive tract in these two farming systems, which can result in a real epidemic with dramatic economic repercussions for livestock farmers in North Eastern Algeria (Over., 1992), such as digestive helminthiasis, which do not systematically lead to death, but rather performance decreases and digestive disorders (Sykes, 1994), avian coccidiosis can cause significant mortality, especially in young chickens between 4 and 8 weeks of age (Berghiche et al., 2018b). These diseases are of particular importance because they are widespread, researched and treated in a preventive and curative manner (Bould et al., 2009).

Studies and scientific data on the different gastrointestinal endoparasites in chickens are still limited; we only find the study on coccidiosis performed by Debbou-Iouknane et al., (2018). Therefore, the purpose of this work is to isolate and identify the main parasites that infect hens reared in traditional and industrial scale in the Wilaya of Souk-Ahras. As well as to carry out an inventory of the oocytes in the region and propose a diagnostic tool to help veterinarians identify them. A qualitative study of gastrointestinal parasitic infestations, from November 2018 to March 2019, was planned and identification of the detected parasite was also considered. Comparison of the identified recorded parasites among different farms along the selected region, Souk Ahras, was done.

\section{MATERIALS AND METHOD}

\section{Ethical approval}

The experiment was carried out according to the National Regulations on Animal Welfare and Institutional Animal Ethical Committee (Van \& Achterbosch, 2008).

\section{Experimental design}

Our work was carried out at the parasitology laboratory level of the Souk Ahras Agro-Veterinary Institute. Ninety faeces samples, from chickens farms distributed along the selected region (Figure 1), were collected. The droppings sampling of chickens of different weights, distributed as follows: 30 samples from 6-week-old adult broiler chickens of Cobb 500 strain; 30 samples from laying hens more than 8 weeks old, Isa Brown strain, and 30 samples from local adult chickens.

\section{Methods and identification technique}

Each sample was examined by a qualitative method called the flotation method, as described by Chauve (1988). Three groups of chickens were chosen and investigated. Fresh desired amount of faeces $(5 \mathrm{~g})$ was used for each group in which 30 samples were taken to be representative for each chicken group. Fresh droppings, required for coproscopy (by the flotation method), collected and not exceeding 24 hours, to ensure accurate identification of parasite species detected (Murthy \& Rao, 2014).

\section{Diagnosis of the different eggs}

All samples of chicken dropping were investigated. The detected parasites were identified according to the keys and description given by Soulsby (1982) and Yamaguti (1958).

\section{Statistical Analysis of the Experimental Data}

The statistical analysis of the experimental data was carried out using statistical software Graph Pad Prisme version 5.01 . 


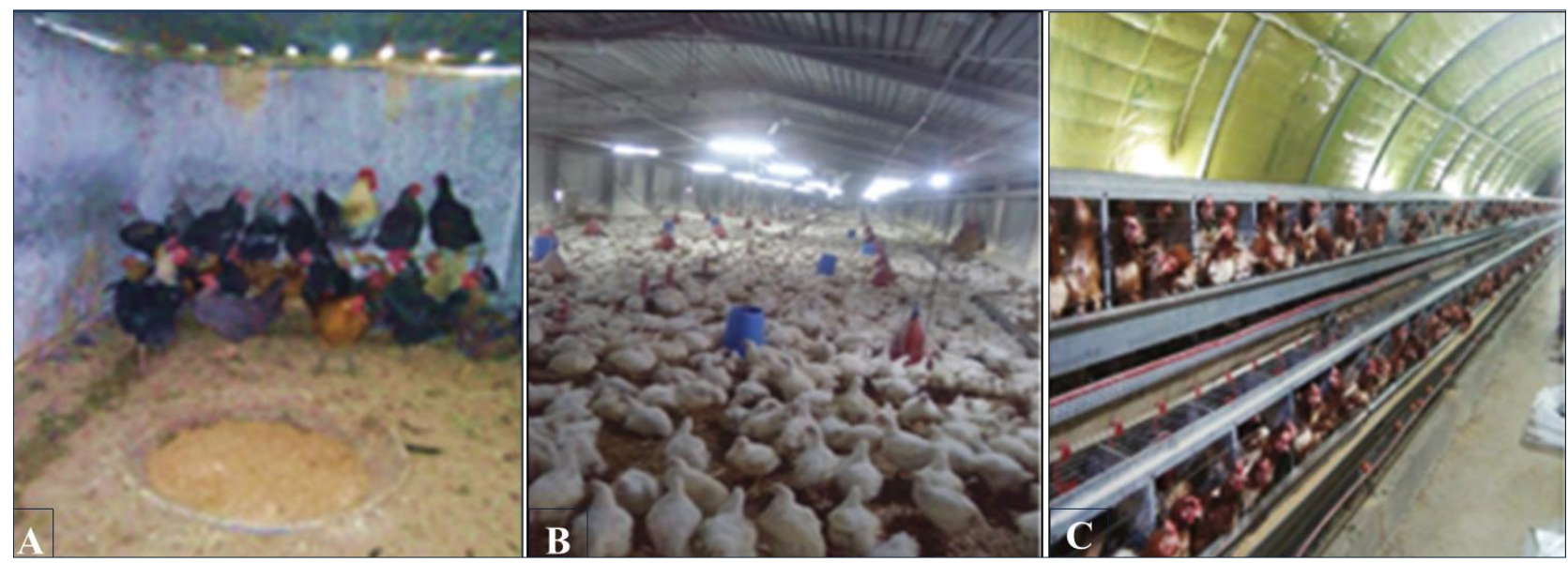

Figure (1): Different poultry farms, (A) Broiler chicken farming; (B) Laying chicken; (C) Local chicken.

\section{RESULTS AND DISCUSSION}

Depending on the data obtained, the main parasitic elements recorded in coprology in local, broiler and laying hen were non-sporelled coccidial oocysts (genus Eimeria) and helminth eggs of Ascaridia galli, Heterakis gallinarium, Syngamus, Trichostrongylus, Tetramers and Capillaria annulata. The existence of these parasites was varied and regulated by the chicken types and inhabitant hygiene.

\section{Diagnosis of the different eggs}

Identification of parasites, based on the morphology of eggs, of the different groups of chickens revealed the presence of the followings:

\section{A.Helminthes}

Ascaridia galli

This parasite was diagnosed by a single granular cell, smooth and thick wall (Fig.2 A and B). Ascaridia eggs are similar to those of Heterakis but have convex side walls.

\section{Hétérakis}

Detection of eggs of Hétérakis were identified by their unique characters of their non-embryonic and non-segmented. The non-segmented egg contains no more than 2 blastomers (most often a single granular cell giving a homogeneous mass appearance). The hull is oval and thick (Figure $2 \mathrm{C}$ and D). These eggs are very similar to Ascaridia's eggs but the sides of the latter are slightly curved while those of Heterakis are almost parallel.

Syngamus

Another genus of parasitic organism was detected in faecal of different chicken types selected in this current study. By means of microscopical examination, Syngamus eggs were observed and characterized. They are relatively large in size, presence of a cap at each pole and a morula generally consisting of 8 cells (Fig. 2 E).

\section{Trichostrongylus}

The genus of Trichostrongylus was also detected. It is characterized by its eggs in which the morula is not filling all the space delimited of the egg body.
The eggs are smooth and their wall is thin and slightly have uneven poles.

\section{Tetrameres}

Helminthic eggs of genus Tetramers were observed and characterized. They are embryonic (vermiform embryo) with slightly uneven poles.

\section{Capillaria}

Genus Capillaria was also recognized by its eggs. They are oval and contain a single yellowish granular cell. They are very identifiable by their flattened polar caps at each pole (Figure $2 \mathrm{~F}$ ).

\section{B.Coccidies}

The second detected non-sporelled coccidial oocysts were diagnosed based on the presence of oocysts in the faeces of investigated chickens. The detected genus was Emeria. To identify Emeria species, oocystes sporulation which is required for complete identification. The egg is spherical to elliptical and has pink colour (Figure 3A and B).

\section{List of parasites according to the type of production} of each breed

Variation in parasite the observation in different types of chickens and their prevalence were found. Hygienic conditions in different frames was also observed but not well studied. Other environmental conditions including conditions like moisture contents, light intensity and temperature are in need to be investigated. Meanwhile, in the current study a list of different parasites detected in chicken droppers are discussed.

\section{A. Broiler chicken}

For broiler chickens, infestation with the following parasites was listed which comprises of Ascaridia, Hétérakis and Emeria eggs. Observation of ectoparasites were also detected (Figure 4). These data are in confirmation with data recorded by Saroj et al., (2015). They recorded species of roundworms, large one include Ascaris sp., and small roundworms of genus Capillaria sp. 


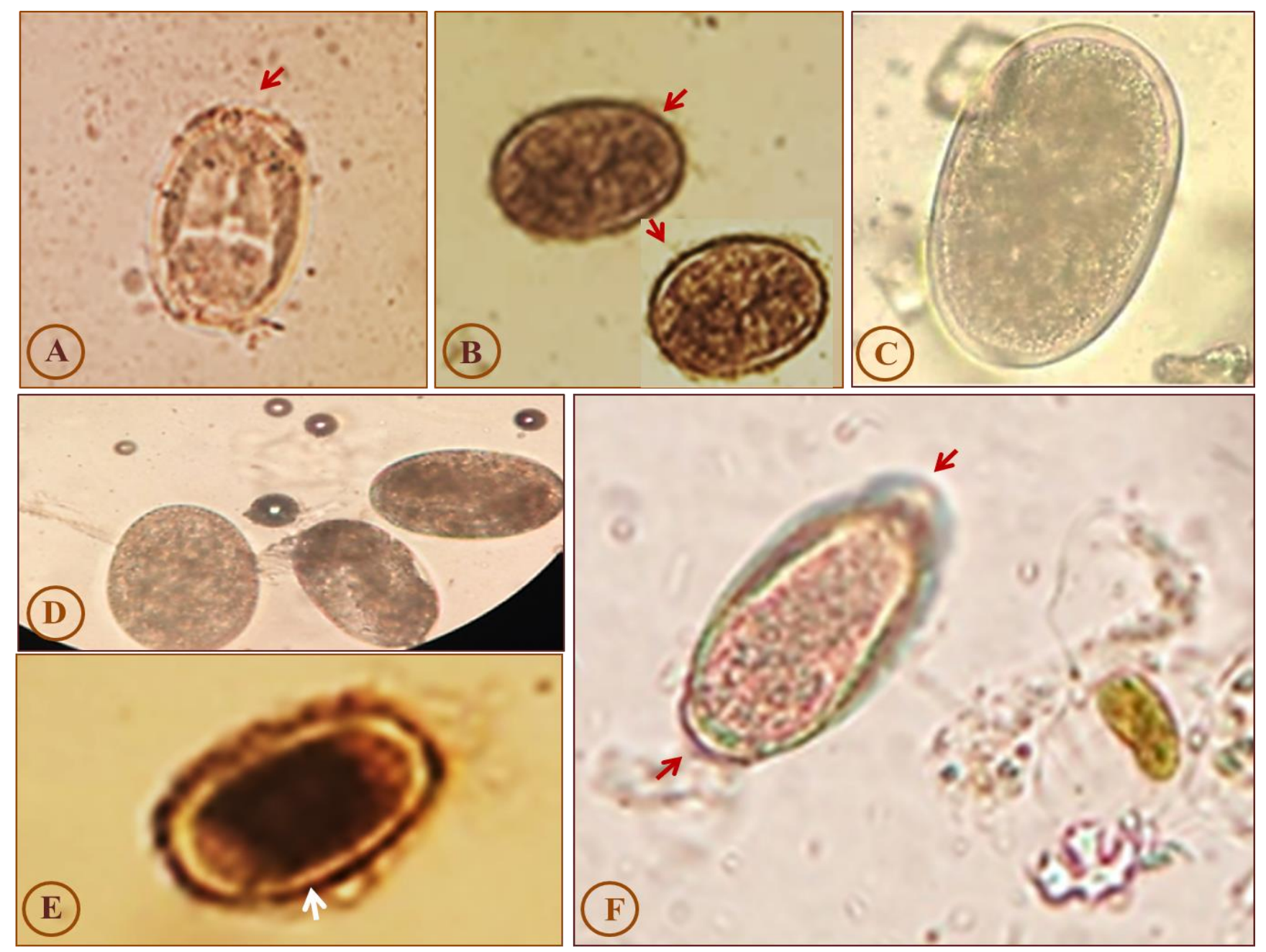

Figure 2: Different genera of parasitic organisms detected in chicken farms, A and B, Ascaridia galli egg with polar convex side wall (arrow); C and D, eggs of Hétérakis with homogeneous mass appearance; E, Syngamus eggs with thickened rough wall (white arrow), and F, egg of Capillaria with oval shape and flattened polar caps at each pole (arrows). 


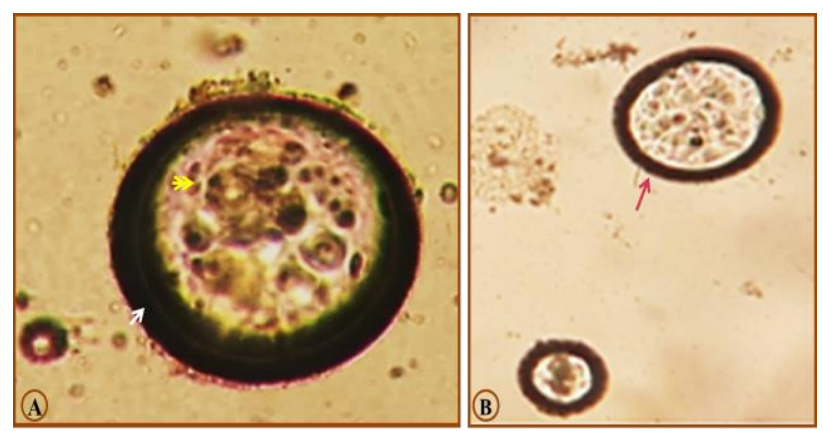

Figure (3): Microscopic observation of Emeria eggs in chicken droppings. X40.

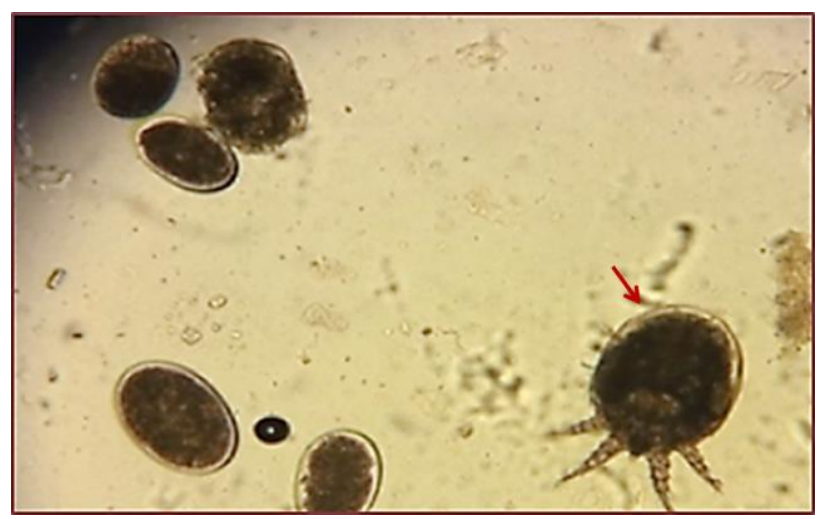

Figure (4): Microscopic observation of ectoparasites (arrow) associated with endoparasites. X40.

\section{B. The laying hen}

Investigation of dropping from the laying hen showed that infection with large worm of gnus Ascaridia $s p$. which was detected by the existence of Ascaridia eggs, was the common existing parasite. This data is in agreement with data recorded previously by Susanna et al., (2019) and Grafl et al., (2017).

\section{Local chicken}

Microscopic observation of different parasites recorded for the third chicken type, local one, revealed the presence of Hétérakis, Emeria, Ascaridia, Syngamus and Capillaria eggs.

The results obtained show a permanent presence of oocytes in the faeces, with very high parasite rates in the local chicken, but these hens are apparently healthy and without any pathological signs.

Verminous parasitism is due to the consumption of intermediate host invertebrates (indirect cycles), which is common in this type of farming, the importance of Ascaridia in chicken is unexpected; given the ethology, contamination is probably due to "occasional hosts" rather than the direct cycle usually described (Elsheikha \& Patterson, 2015).

In extensive village farms, a study revealed a varied abundance of parasites, which depends on the species (host/parasite) and the seasons (McDougald, 1998).

\section{Prevalence of parasites according to the type of production of each breed}

Microscopic examinations of poultry carried out for 90 semi-industrial farms (i. e. 30 broiler and 30 laying hen farms) and 30 traditional farms have shown oocystal excretion, egg excretion of Ascaridia, Heterakis gallinarium, Syngamus, Capillaria annulata and ring egg excretion of taenia is rarely encountered.

In total, helminthic species have been identified, including four nematodes and one protozoa species coccodial, in terms of worms, the frequencies of Ascaridia, and Heterakis gallinarium are more prevalent compared to others (Figure 6). The number of excretion of Ascaridia eggs in industrial poultry farms (broilers) is close to that found in traditional poultry farms (not significant difference) while the difference between them and that of the laying hen is very marked.

With regard to oocystal excretion, which is very frequent, the prevalence values are important to compare between industrial (meat) and farm animal husbandry, whereas there is a significant difference compared to laying hen husbandry (false negative); The high prevalence of infestations in local chicken can be explained by the traditional nature of this type of farming, without any technical and health monitoring. (Alders, 2015); The main risk associated with exposure of samples to high outdoor temperatures is the evolution of larvae inside eggs, sometimes leading to hatching, which then makes it very difficult or impossible to detect them by sodium chloride flotation. (Silverman \& Campbell, 1959).

The consequences of the presence of litter in the droppings were initially difficult to measure the precise weight of the droppings (necessary for dilution) because they were most often inseparable from the litter (Font-Palma, 2012). Then, it hindered the reading of the blades in total flotation because even after a preliminary filtration, the non-figured elements remained in very important quantity. The presence of eggs in droppings does not necessarily show clinical signs without reaching an infestation threshold; There is no correlation between the amount of eggs per gram of faecal matter and the consistency of the faeces (Daş et al., 2011). However, they suspect that a dilution effect that could distort the results, in other studies of the same type have not found parasites that we have found in farms in the Souk Ahras region (Fig. S1).

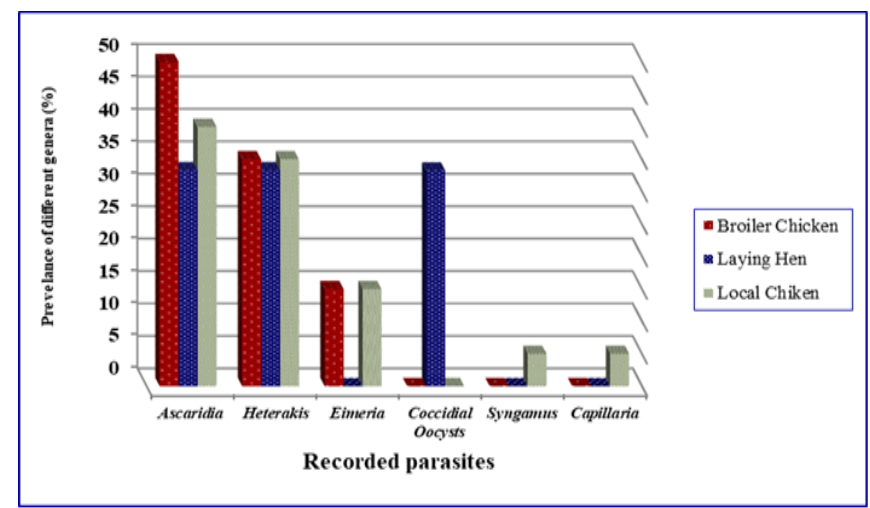

Figure (6): Prevalence of gastrointestinal parasites detected in different chicken types selected for the current study. 


\section{CONCLUSION}

The role of the poultry sector, clearly defined but it is confronted with major avian diseases leading to significant mortality, performance losses and economic losses; The development of poultry farming is therefore linked, among other things, to the control of these pathological constraints, including digestive parasitosis of poultry caecum.

Indeed, due to its etiological plurality and its repercussions on zootechnical performance, cæcum intestinal parasitism deserves particular attention in both intensive and extensive systems, this plurality reflects the need for precise control measures based on etiological and epidemiological knowledge of caecum digestive parasitism in the different types of livestock, Isolation and identification of intestinal parasites involved 90 chickens from 3 types of semi-industrial farms (broilers and layers) and traditional farms (farm chickens); The results obtained show intestinal parasitism in poultry regardless of the type of farming, the intestinal parasites found in industrial chickens as divagants are coccidia (such as Eimeria) and in farm chicken we have identified several types of oocytes, this study found that heavy losses due to parasitism are recorded in both semi-industrial and traditional livestock systems, the permanent presence of chicken parasites, linked to the farming method practised in the Souk Ahras region, requires the implementation of control measures combining anti-parasitic treatments for poultry with the improvement of habitat hygiene and food quality; Low animal productivity does not allow farmers to invest in adequate pest control, raising awareness among farmers, at least about sanitary control methods, could give better days to this type of production. Nevertheless, some medicinal plants in rural areas for their anti-parasitic action continue to have an effect.

\section{REFERENCES}

ALDERS, R. G. 2004. Poultry for profit and pleasure (No. 3), Food \& Agriculture Org.

ALLOUI, N., AND O. BENNOUNE. 2013. 'Poultry production in Algeria: Current situation and future prospects', World's Poultry Science Journal 69(3), 613-620. https://doi.org/10.1017/S0043933913000615.

BERGHICHE, A., KHENENOU, T., BOUALLEG, I. M., BOUACIDA, A., AND I. LABIAD. 2018a. Study of Factors Linked to the Variation in Rentability in the Farming of Broiler Chickens in Northeast Algeria. Animal Review, 5(2), 22-33.

BERGHICHE A, KHENENOU T, AMIRA. B, AMINA. G AND I. LABIED. 2018b. Morphohistological study of coccidiosis in broilers in the Souk Ahras region, Algeria. Online J. Anim. Feed Res., 8(6): 136-144.

BOULD, J. G., ELSHEIKHA, H. M., AND T. A. MORSY. 2009. Avian coccidiosis: the basic pathology to control. J Egypt Soc Parasitol, 39, 85-98.
CHAUVE, C. M. (1988). Contribution a l'etude des coccidies de l'oie dans la region du sud-ouest de la france. Proposition d'une cle de diagnose des differentes especes, basee sur la morphologie de l'ookyste sporule. Avian Pathology, 17(2), 433-440.

DAŞ, G., SAVAŞ, T., KAUFMANN, F., IDRIS, A., ABEL, H., AND M. GAULY. 2011. Precision, repeatability and representative ability of faecal egg counts in Heterakis gallinarum infected chickens. Veterinary parasitology, 183(1-2), 87-94.

DHAMA, K., LATHEEF, S. K., MANI, S., SAMAD, H. A., KARTHIK, K., TIWARI, R., AND V. LAUDADIO. 2015. Multiple beneficial applications and modes of action of herbs in poultry health and production-A review. Int $\mathrm{J}$ Pharmacol, 11(3), 152-176.

DEBBOU-IOUKNANE, N., BENBAREK, H., AND A. AYAD. 2018. Prevalence and aetiology of coccidiosis in broiler chickens in Bejaia province, Algeria. Onderstepoort Journal of Veterinary Research, 85(1), 1-6.

ELSHEIKHA, H., AND J. S. PATTERSON. 2013. Veterinary Parasitology: Self-Assessment Color Review. CRC Press.

FONT-PALMA, C. 2012. Characterisation, kinetics and modelling of gasification of poultry manure and litter: An overview. Energy Conversion and Management, 53(1), 92-98.

Grafl B, Polster S, Sulejmanovic T, Pürrer B, GUGGENBERGER B, HESS M. 2017. Assessment of health and welfare of Austrian laying hens at slaughter demonstrates influence of husbandry system and season. Brit Poultry Sci. 58:209-215.

MCDOUGALD, L. R. 1998. Intestinal protozoa important to poultry. Poultry science, 77(8), 11561158.

MURTHY, G. S. S., AND P. V. RAO. (2014). Prevalence of gastro intestinal parasites in ruminants and poultry in Telangana region of Andhra Pradesh. Journal of parasitic diseases, 38(2), 190-192.

OVER, H. J., JANSEN, J., AND P. W. VAN OLM. (1992). Distribution and impact of helminth diseases of livestock in developing countries (No. 96). Food \& Agriculture Org.

OUESLATI, T., ALAOUI, M. K., ICHKHAKH, A., CALLEGARIN, L., DE CHAZELLE, C. A., AND E. ROCCA. 2020. 1st century BCE occurrence of chicken, house mouse and black rat in Morocco: Socio-economic changes around the reign of Juba II on the site of Rirha. Journal of Archaeological Science: Reports, 29, 102162.

SAROJ KUMAR, RAJAT GARG, CORRESPONDING AUTHOR HIRA RAM, P. S. MAURYA, AND P. S. BANERJEE (2015). Gastrointestinal parasitic infections in chickens of upper gangetic plains of India with special reference to poultry coccidiosis. J Parasit Dis. 39(1): 22-26.

SILVERMAN, P. H., AND J. A. CAMPBELL. (1959). Studies on parasitic worms of sheep in Scotland: I. Embryonic and larval development of Haemonchus contortus at constant conditions. Parasitology, 49(12), 23-38. 
SOULSBY, E.J.L. 1982. Helminths, Arthropods and Protozoa of Domesticated Animals. 7th edition, Bailliere Tindall and Cassell Ltd. London.

SUSANNA LOLLI, GUIDO GRILLI, LORENZO FERRARI, PAOLO FERRARI \& VALENTINA FERRANTE (2019) Effect of range use on endoand ectoparasite infestation in italian organic egg production, Italian Journal of Animal Science, 18:1, 690-695, DOI: 10.1080/1828051X.2018.1564377.

SYKES, A. R. 1994. Parasitism and production in farm animals. Animal Science, 59(2), 155-172.

WINDHORST, H. W. 2006. Changes in poultry production and trade worldwide. World's Poultry Science Journal, 62(4), 585-602.

VAN HORNE, P. L. M., \& ACHTERBOSCH, T. J. (2008). Animal welfare in poultry production systems: impact of EU standards on world trade. World's poultry science journal, 64(1), 40-52.

YAMAGUTI, S. 1958. Systema Hilminthum. Vol. I, II, III and V, Intersience Publishers, Inc. New York, USA..

\footnotetext{
الفحص المجهري أداة تشخيصية محورية في علم طفيليات الطيور

برغيش امين، بولبدة ناجي1، عوادي امل، غمايدية ملاك، خنتو طارق2

1 مخبر علوم وتقنيات الاحياء، معهد العلوم الفلاحية و البيطرية، جامعة ححمد الثريف، مساعدية سوق اهر اس، الجزائر.

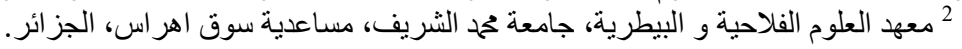

الملخص العربــــي

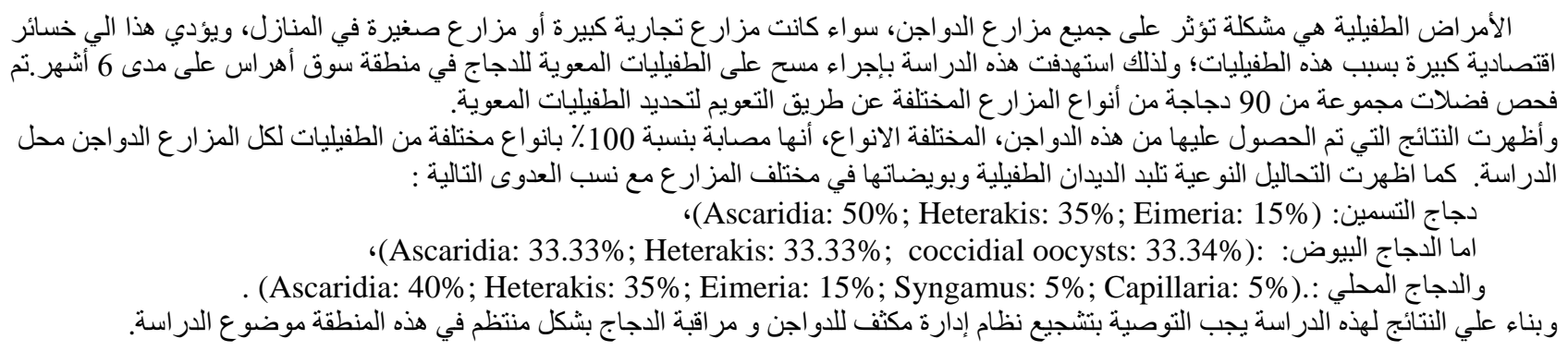

